Editorial

\title{
Women and Philosophy: An Initial Move Towards a More Inclusive Practice of Philosophy in the Philippine Context
}

\author{
Marella Ada V. Mancenido-Bolaños \\ and Darlene O. Demandante ${ }^{1}$
}

\section{Introduction}

$\mathrm{P}$ hilosophy, in general, is a male-dominated discipline. Some fifty years ago, pursuing a career in philosophy was less imaginable to women than to men. Women who choose a career in philosophy are often in danger of being labelled as insane because of the often-conventionalised roles attributed to women in society as domestic carers who are confined to the walls of a home's private space. On the other hand, philosophy as a discipline which is identified with objective intellectual aptitude was once exclusive to the male gender and associated with ideas such as "mind and choice, freedom from body, autonomy, and the public." 2 Today, while there have been vast improvements in the experiences of women doing academic philosophy, women continue to be one of the visible groups of minorities in this field of work.

In 2009, the feminist philosopher Sally Haslanger published an article in Hypatia: A Journal of Feminist Philosophy ${ }^{3}$ where she expressed her rage about how women in academic philosophy communities are being treated. Her striking observations include the fact that contributions of women philosophers remain undervalued. As a matter of fact, top journals and tenure track positions in philosophy departments are often male dominated.

\footnotetext{
${ }^{1}$ For correspondence, readers may contact Dr. Marella Ada V. Mancenido-Bolaños at mmbolanos@ust.edu.ph and Dr. Darlene O. Demandante at dodemandante@ust.edu.ph.

${ }^{2}$ Raia Prokhovnik, Rational Woman: A Feminist Critique of Dichotomy (Loundon: Routledge, 1999), 103. See also, Mari Mikkola, The Wrong of Injustice: Dehumanization and Its Role in Feminist Philosophy (Oxford: Oxford University Press, 2016).

${ }^{3}$ See Sally Haslanger, "Changing the Ideology and Culture of Philosophy: Not by Reason (Alone)," in Hypatia: A Journal of Feminist Philosophy, 23:2 (April-June 2008).

(c) 2020 Marella Ada V. Mancenido-Bolaños and Darlene O. Demandante https://www.kritike.org/journal/issue 26/mancenido-bolanos\&demandante june2020.pdf ISSN 1908-7330 


\section{WOMEN AND PHILOSOPHY}

Haslanger also noted how women still suffer blatant discrimination in the academe, especially in terms of the existence of an overarching male-biased schema of hiring faculties. She pointed out the strong stereotyping of women's role in the academe as half-baked philosophers and full-time house caretakers due to strong cultural bias.

The same observations were echoed by Linda Alcoff in her edited collection of autobiographical essays by women who have succeeded in philosophy. ${ }^{4}$ Alcoff's introduction to the edited volume narrates some struggles of women in the academe, spanning back to the experience of graduate students in the United States who were first admitted to the graduate school program to become professional philosophers. Alcoff narrates how female graduate students of philosophy experience standard inferior treatment as they are subjected to unique challenges such as when they are often compelled to act like their male counterparts and exhibit male virtues. ${ }^{5}$ She further opined that faced with these specific challenges which determine our success in philosophy as a profession, we often resort to silence and subservience.

Aside from the professional challenges, women are also subjected to overt and explicit forms of sexual harassment. ${ }^{6}$ Women, moreover, suffer from the stress of keeping pregnancies secret or delaying their pregnancies prior to tenureship. Some are encouraged to keep one's child-care responsibilities invisible, if not to a minimum, whereas men are admired for attending to their children. A number of institutions enforce compulsory heterosexuality and would often not hire women who deviate from normative traditional standards. Within these conditions, Haslanger and Alcoff recognise that thriving and even surviving can be a painful and difficult experience for women. Their main reference was Western academia, wherein they both belonged. Their observations did not cover what is beyond that, especially in Asian, African, or Latin American contexts wherein women suffer the same fate if not even worse.

In the Philippines' purportedly "big four" universities, where there are existing departments of philosophy, the range of the proportion of female

\footnotetext{
${ }^{4}$ Linda Martín Alcoff, ed., Singing in the Fire: Voices of Women in Philosophy (New York: Rowman and Littlefield, 2013).

${ }^{5}$ Women often had to ignore their body pains, inconveniences both physical and emotional in order to function 'efficiently.'

${ }^{6}$ Attesting to what Alcoff has described above, one of the editors for this special issue presented a paper on Simone de Beauvoir's Theory of Sexual Liberation from the History of Sex in a National Conference with the theme, Discoursing Human Sexuality: Eros, Ethos, Nous, organized by the Philosophical Association of the Philippines (PAP, Inc.), held last 10 to 12 April 2012. Ninety percent of the participants were male Philosophy teachers. During the open forum, some participants raised questions which are loaded with sexual innuendos rather than inquire about the paper which was presented.
}

(C) 2020 Marella Ada V. Mancenido-Bolaños and Darlene O. Demandante https://www.kritike.org/journal/issue 26/mancenido-bolanos\&demandante june2020.pdf ISSN 1908-7330

$(\mathrm{Cc}) \overline{\mathrm{BY}-\mathrm{NC}-\mathrm{ND}}$ 
faculty members is between $32-35 \%$. Outside of Manila, the data is not any better. For example, in the University of San Carlos, Cebu only 22\% of philosophy faculty are women and in Ateneo de Davao, only $29 \%$ are women. Only the faculty profile of the University of the Philippines, Baguio looks promising in terms of equality in gender distribution. However, while this looks good, it could not stand to ensure that female philosophy faculties do not or did not go through the negative experiences described previously, or whether the procedures for hiring faculties, tenureship, and research environment provide equal opportunities for all genders. ${ }^{7}$

As there is hardly any data about the status of women doing philosophy in Philippines, or Filipina women doing philosophy, our insights are limited to our own experiences and the experiences of our colleagues whom we have had the chance of conversing with, as well as a small number

7 In terms of publication, we use Kritike as a reference to demonstrate women's underrepresentation in philosophy. Kritike has only published forty-two (42) articles by women authors in a span of twelve (12) years (2007-2019). These 42 articles are attributable to twentyfive (25) female authors. While the journal utilises a double-blind review which removes the gender bias and focuses solely on the merit of the paper, the number of women who published in Kritike attests to the fact that in terms of publication, women are still a minority. Kritike's editorial board, moreover, is also predominantly comprised of men. There are only eight (8) editors and three (3) members in the International Advisory Board who are women. Fleurdeliz Altez-Albela, Melanie Mejia, Marella Mancenido-Bolaños, Darlene Demandante, and Tracy Llanera were initially the only female members in the editorial board because they were the only ones who finished their graduate degrees in the early years of the journal. Gian Agbisit, Julia De Castro, and Pia Tenedero were invited as part of the board when the journal was already expanding.

Women are also underrepresented in major philosophical associations in the country both in terms of officership and membership. Currently, Philosophical Association of the Philippines (PAP, Inc.) only has two (2) women who are members of the board. The same is the case with the Philippine National Philosophical Research Society (PNPRS). On the other hand, there are no women in the board of officers of the Philosophical Association of Visayas and Mindanao (PHAVISMINDA). Today, there is still no professional association for Filipina philosophers which can prove to be essential in terms of improving the presence and participation of women in philosophy in the Philippines or Filipina philosophers in general.

On the positive side of things, international scholarship for Filipina women in philosophy has significantly improved as there have been more and more women who have ventured outside the Philippines either to pursue their doctorate in philosophy or become prominent scholars. They pushed their way into the academe with sheer determination, talent, and guts. Tracy Llanera, Kelly Agra, Chistine Tan, Rowena Palacios, Leslie dela Cruz, Lovelyn Paclibar, Preciosa de Joya, PJ Mariano-Capistrano, and Darlene Demandante to name a few. Among these women intellectuals, Tracy Llanera has won two post doctorates in prestigious universities and is about to launch two books: one with Palgrave Macmillan and the other one with Routledge. Llanera's story is an inspiring example of how women push their way into academic philosophy. Her article "The Brown Babe's Burden" published by Hypatia in 2019 narrates her experiences of struggling against the challenges of being a coloured woman in a male dominated field. See Tracy P. Llanera, "The Brown Babe's Burden," in Hypatia: A Journal of Feminist Philosophy, 34:2 (2019).

(c) 2020 Marella Ada V. Mancenido-Bolaños and Darlene O. Demandante https://www.kritike.org/journal/issue 26/mancenido-bolanos\&demandante june2020.pdf ISSN 1908-7330 


\section{WOMEN AND PHILOSOPHY}

of articles that attempt to compile the work of Filipino philosophers. The closest we had to ascertaining these contributions of prominent women doing philosophy was Demeterio's compilation of the works of Filipino philosophers wherein there were only four female names Angeles, Canilao, Mananzan, and Quito. ${ }^{8}$

This list was, of course, incomplete as well as outdated; only the contributions of seasoned philosophers and pioneers of philosophical thought in the country have been counted, wherein the majority, obviously, are male. The limited data that we have already provides us a glimpse of the unfortunate reality that philosophy in the Philippine academe is not ready for women. There has been some neglect, whether intentional or not, and it continues to be challenging for women to thrive in this current environment. There is hardly any research on the status of women in Philosophy, not to mention that a number of people have a twisted and biased understanding of feminism and feminist philsophy. There are attacks on the credibility of feminism as an approach to social problems, ${ }^{9}$ and more often than not, our complaints are labelled as emotional outbursts rather than symptoms of an existing discrimination.There is, furthermore, a lack of serious engagement with feminist paradigms which have great potential for addressing a number of social issues. The struggle we experience because of our gender does not even include the fact that doing philosophy is not considered as a serious career in the Philippines.

\section{A Call for Improving Women's Participation in Philosophy}

When we began working on this special issue, we thought we had a very simple and straightforward goal that is to solicit works by women doing philosophy in the academe in order to give more attention to the interesting work that they have been doing. Little did we know that we would be confronted with a glaring gap in the data on the status of women doing philosophy in Philippine academic circles. There is no doubt that lists of women authors and taxonomies of articles in philosophy written by these authors exist in different scholarly studies, but they remain incomplete and unorganised. There is no existing centralised database which would have made it easier to form a community of women scholars who have interest in

${ }^{8}$ See Feorillo Petronillo Demeterio III and Lesline Anne L. Liwanag, “Emerita Quito, Mary John Mananzan, and Filipina Philosophy: A Critical Comparison of the Thoughts of the Two Leading Female Philosophers of the Philippines," in Humanities Diliman, 15:1 (January-June 2018).

9 See Jeremiah Joven Joaquin, "Feminism without Philosophy: A Polemic," in Kritike: An Online Journal of Philosophy, 10:1 (June 2016) and Noelle Leslie G. dela Cruz, "Why Social Movements Need Philosophy (A Reply to "Feminism without Philosophy: A Polemic" by Jeremiah Joven Joaquin)," in Kritike: An Online Journal of Philosophy, 11:1 (June 2017).

(c) 2020 Marella Ada V. Mancenido-Bolaños and Darlene O. Demandante https://www.kritike.org/journal/issue 26/mancenido-bolanos\&demandante june2020.pdf ISSN 1908-7330

$(\mathrm{Cc}) \overline{\mathrm{BY}-\mathrm{NC}-\mathrm{ND}}$ 
pushing forward the agenda of a fair and equal treatment of women in the academe or simply support each other's research endeavours.

This issue of Kritike aims to present women embarking on the task of doing philosophy in the Philippines. It is comprised of ten papers that directly engage feminist paradigms, contribute to various issues, and/or do conceptual philosophy in different areas of research interests. The contributions in this volume are organised into three categories.

The first group of papers tackle Feminist paradigms as conceptual tools on how we should approach philosophising, in order that it be sensitive to the social identity of the female gender.

Josephine Pasricha in her piece titled, "Systems Thinking, Gender, and Sex," shares with us a survey document on the success of the United Nations Millennium Development Goals of 2000-2015, focusing on its provisions on gender equality and women empowerment. She used systems thinking and presencing as methods to lay down her arguments. She also experimented on a new trend of writing with one-sentence paragraphs "continuously flowing in a narrative." Pasricha ended her essay with recommendations on how the academe can further their research and advocacy on policies using systems thinking.

Kelly Agra, in "Epistemic Injustice, Epistemic Paralysis, and Epistemic Resistance: A (Feminist) Liberatory Approach to Epistemology," offers a thought-provoking "interrogation of the ways in which power relations between social identities create conditions of hermeneutical inequality and testimonial privileging and/or marginalization within the field of philosophy." Her project of an epistemic liberatory framework of philosophy draws from philosophical literature in feminist, decolonial, and critical race studies. She argues that if philosophy were to develop as a just institution, there is a need to explore the role of social identity in knowledge formation. The paper makes powerful use of feminist critique in order to surface what Agra calls, "philosophy's insensitivity to its own insensitivity."

In "Immanence and Autobiography: Gilles Deleuze's a life and Sarah Kofman's autobiogriffure," Jean Tan stages an encounter between the autobiographical writings of Kofman and Deleuze's "Immanence: A Life," in order to draw out the relation between autobiography and philosophy. In her insightful discussion about these two thinkers whose writings significantly differ, she confirms her initial intuition that "there is something courageous and transgressive in the way in which Kofman refused to disavow the particularity of her voice for the sake of attaining the anonymity of the authorial philosophical voice" thus establishing the significance of the feminine voice which is often dismissed as hysterical, emotional, and subjective. The most striking finding of Tan's reflection is that autobiography, as a form of writing, opens a wound in philosophy which enables philosophy

(c) 2020 Marella Ada V. Mancenido-Bolaños and Darlene O. Demandante https://www.kritike.org/journal/issue 26/mancenido-bolanos\&demandante june2020.pdf ISSN 1908-7330 


\section{WOMEN AND PHILOSOPHY}

to confront its inadequacies and dissonance between consciousness and its field.

Ma. Theresa Payongayong, in her piece titled "Reflexive-Liberative Feminist Ethics," aims to "contribute to the enrichment of knowledge on Filipino feminist ethics." She attempts to establish a Filipino feminist ethics based on the narratives of select Filipino feminists. She asserts that ethical issues are rooted in the traditional notion of women and their gender roles. She ends her paper by encouraging feminists not to simply reject or accept a value, but to stand by their informed decision. She then suggests that a Filipino feminist ethics must be reflexive, where women are given the chance to choose and understand their choices. It must also be liberative because these choices are not for the benefit of women alone, but for the benefit of humanity as well.

The second group of papers discusses the Feminist paradigm as applied to social issues. We describe these papers as provocations on how feminist paradigms could possibly make a difference when looking at some of the problems in society.

Marella Mancenido-Bolaños's article titled, “Iris Marion Young's Faces of Oppression and the Oppression of Women in the Responsible Parenthood and Reproductive Health Act of 2012" takes us into the tedious task of creating a bill that consistently rejects the rights of women over their own bodies. She describes how policies which are not grounded in the experiences of women turn out to be oppressive and counterintuitive to women's welfare. She invites us to reflect about how a public policy, enactment, or bill which is disconnected from the reality of women's lives can cause serious problems for the welfare of women. In her reflection, she used Iris Marion Young's faces of oppression to show the various forms of oppression experienced by women during the crafting of the bills.

In "When Your Country Cannot Care for Itself: A Filipino Feminist Critique of Care-based Political Theories," Noelle Leslie Dela Cruz addresses the politics and crisis of care. She investigates the plight of women being the primary caregiver be it in the form of paid or unpaid labor. She considers the crisis of care as a form of injustice as it is still considered to be in the sphere of "women's work." She then criticizes the problem of poverty and the incapacity of the Philippine government to provide economic security to its citizens which leads to the challenging experience of women who need to provide for their families and women who are forced to leave the country and become underpaid domestic workers. Despite the fact that these overseas women domestic workers keep the economy afloat, the government still does not provide them with policies to ensure their security.

The third group of papers consists of women writing on various topics about philosophy engaging in the exercise of redirecting away from

(c) 2020 Marella Ada V. Mancenido-Bolaños and Darlene O. Demandante https://www.kritike.org/journal/issue 26/mancenido-bolanos\&demandante june2020.pdf ISSN 1908-7330

(c) $)$ BY-NC-ND 
more commonly known perspectives in philosophy, and suggesting alternative conceptual take on politics, aesthetics, thinking, scientific approach, and literature.

In "Aesthetics, Politics, and the Embodied Political Subject," Darlene Demandante explores the link between the body, aesthetics, and politics using the works of Jacques Rancière. She looks into the relation between political subjectivity, aesthetics, and politics, arguing that even the unassuming action of the body can be political. Her essay explores the varied potentials of aesthetics to send out political meanings through the action of the body."

Maria Majorie R. Purino's paper titled “A Revisiting of Heidegger's Thinking-Thanking and Zen's Non-rationality," draws on the connection between Heidegger's thinking and Zen Buddhism's notion of satori in order to deduce an idea of thinking that is not calculative but rather meditative. "This meditative thinking," she wrote, is "a kind of thanking." Purino adds that thanking "springs from memory," a remembrance that is "brought about by a sense of fondness of that which is being remembered." In her careful explication of the connection between Heidegger's notion of thinking and Zen Buddhism's notion of satori, Purino argues that bereft thinking characteristic of our time could be eliminated if we take the stance of meditative thinking and apply Zen's non-rationality.

Vida Valverde, in "Argument from Psychological Difference: Why It Makes Sense to Be a Scientific Realist Than an Instrumentalist," discusses the difference between scientific realism and instrumentalism. Using Devitt's theory as a foundation for her arguments, she offers us reasons why scientific realism should be favored over instrumentalism. She asserts that this is ultimately because scientific realism is grounded in "existing material reality," whereas instrumentalism only offers us a convenient fiction that systematizes our experience.

Lastly, Fleurdeliz Altez-Albela in her piece titled "Looking Through the Sweetheart, Flamboyant and Insane: Rereading Rizal's Critique of the 19 Century Filipina in Noli Me Tangere," shows "how Rizal critically portrayed the struggles of the Filipina as an individual and as a member of the state." Through an analysis of three Filipina characters in Rizal's novel, she speculates about his depiction of some stereotypes of the female native during Spanish colonization. In her analysis of the three female characters, she offers a glimpse of the Philippine national hero's musings about how to be identified as a dignified and empowered Filipina. Altez-Albela's paper goes against the grain of what is being argued in this issue, particularly on the problem of establishing the identity of women as providing a role of support in building a masculine institution such as the state. This paper invites ambivalences and tensions in the conceptual understanding of what

(c) 2020 Marella Ada V. Mancenido-Bolaños and Darlene O. Demandante https://www.kritike.org/journal/issue 26/mancenido-bolanos\&demandante june2020.pdf ISSN 1908-7330 
is feminine in order to push further the discourse about women in philosophy.

\section{Conclusion: Of Purposes and Hopes}

We exerted the effort to produce this collection with the firm belief that it is about time for a special issue on women doing philosophy in the Philippines to be published and made available to the public, if we are to move towards a better direction in the manner that we do philosophy in the country. Having in mind questions such as "At what level do we want to bring our philosophising?" and"In what manner do we want to take the direction of philosophy forward?", we think that one of the many possible replies to these questions pushes us to be more inclusive and find new ways of thinking that could address the undervalued contributions of women who are doing philosophy in the country. We talk about doing philosophy at the margins, but we must check our privileges as members of the academe and become sensitive to the aggressions that academic philosophy can often be blind to.

The set of problems we have addressed in this special issue is just the tip of the iceberg. We thus hope that this work may serve as an invitation for a more inclusive practice of philosophy from marginalised groups (in terms of gender, race, disability, etc.). It is about time that we focus on recognising these existing vulnerabilities and move forward in a manner that does not attempt to merely save face (the masculine way) but engages in these painful realities in order to set the stage for more potential answers. Ultimately, we hope to start the practice of seriously recognising Filipina philosophers or women doing philosophy in the Philippines in conferences, panels, journals, public debates, and workshops in order to open more spaces for women in philosophical discourses.

We hope to embark on an ambitious project of paving the way, as Quito did thirty years ago, when she laid the foundations for faculties to have a collective voice, ${ }^{10}$ only this time with emphasis on women and other minorities in philosophy. Through collective action and the power of community where members complement each other's shortcomings, and highlight each other's strengths, we aspire to build a community of women philosophers who can support each other and help each other thrive amidst the specific challenges of engaging in philosophy as a gendered person. Most importantly, we hope to invite a community of women philosophers and academics who take interest in issues surrounding Filipina philosophers.

${ }^{10}$ Anne Quito, "Emerita Quito: The Philippine's greatest female philosopher has died," in Quartz (17 September 2017), <https://qz.com/725370/emerita-quito-the-greatest-forgottenfilipino-philosopher-has-died/>.

(c) 2020 Marella Ada V. Mancenido-Bolaños and Darlene O. Demandante https://www.kritike.org/journal/issue 26/mancenido-bolanos\&demandante june2020.pdf ISSN 1908-7330

(c) BY-NC-ND 


\section{A Tribute to Dr. Josephine Acosta-Pasricha (1945-2020)}

When we started brainstorming about this issue, Dr. Josephine Acosta-Pasricha was the first person we had in mind, being the only professor who taught us feminism and women empowerment back in college, at the University of Santo Tomas. She was the first to respond to our invitation and was also the first to submit her paper. It is remarkable that at her age and stature, she humbly submitted her paper to be reviewed and edited by her former students. It is even more impressive how she edited her paper according to the suggestions of her reviewers. She mentioned that once her paper gets published, she wanted to show it to her mentors from the University of Pennsylvania.

In our final correspondence last 14 May 2020, she submitted the final edited version of her essay, telling us that "you can still ask me to change some things until it is finally published." We are publishing her work in the exact format she submitted it. On 1 May 2020, she sent an email explaining how narratology, systems thinking, and presencing works. She said, "I was regretting that Romy ${ }^{11}$ is not alive to see this post-human Data Storytelling. He would have been happy and in glee." She has joined him too soon.

Dr. Josephine Maxima Acosta-Pasricha was a Ford Foundation fellow at the University of Delhi from 1976 to 1977, where she studied Oriental Aesthetics and Philosophy. In 2000, she finished her Doctorate in Philosophy (summa cum laude) in the University of Santo Tomas with a dissertation titled, "A Hermeneutic Translation in Filipino and Gadamerian Meditation of the Indian Epic, Ramayana." As a renowned Indologist, she later edited Marvin Reyes and Paz Panganiban's Filipino translation of the Kama Sutra.

She was an Assistant Professor at De La Salle University, Manila from July 1985 to March 1994. She was also a Professorial Lecturer at the University of Santo Tomas from July 1966 to March 2013, where she taught Feminism, women empowerment, Aesthetics, and Hermeneutics. Dr. Pasricha was also a Visiting Scholar at San Carlos University, Cebu from April 2000 to March 2013, and a Visiting Scholar on Systems Thinking at the University of Pennsylvania from 2010 to 2013. Her recent publications include The Future is Love and Marriage (2015) and Story Scapes: Pope Francis Effect (2015).

Where she pushed the frontiers of philosophy in the Philippines through her scholarship, we remember her as a teacher who nurtured her students into finding their own voices through her reassuring demeanor. She

${ }^{11}$ Br. Romualdo "Romy" E. Abulad, SVD, Ph.D. was a once a student, and later a colleague of Dr. Pasricha. Br. Romy transitioned to the next life last 17 December 2019, about half a year before Dr. Pasrischa's passing. Both intellectuals were pioneers of philosophy in the Philippines.

(c) 2020 Marella Ada V. Mancenido-Bolaños and Darlene O. Demandante https://www.kritike.org/journal/issue 26/mancenido-bolanos\&demandante june2020.pdf ISSN 1908-7330 
epitomised a passionate disposition towards teaching about feminism and the plight of women. Dr. Pasricha was gentle yet firm in her scholarly interests and advocacies. She knew how to draw strength from her femininity and demonstrated how women should be confident and empowered amidst the male-dominated discipline of philosophy.

Department of Philosophy, University of Santo Tomas, Philippines

\section{References}

Alcoff, Linda Martín, ed., Singing in the Fire: Voices of Women in Philosophy (New York: Rowman and Littlefield, 2013).

Dela Cruz, Noelle Leslie G., "Why Social Movements Need Philosophy (A Reply to "Feminism without Philosophy: A Polemic" by Jeremiah Joven Joaquin)," in Kritike: An Online Journal of Philosophy, 11:1 (June 2017).

Demeterio, Feorillo Petronilo III and Leslie Anne L. Liwanag, "Emerita Quito, Mary John Mananzan, and Filipina Philosophy: A Critical Comparison of the Thoughts of the Two Leading Female Philosophers of the Philippines," in Humanities Diliman, 15:1 (January-June 2018).

Haslanger, Sally, "Changing the Ideology and Culture of Philosophy: Not by Reason (Alone)," in Hypatia: A Journal of Feminist Philosophy, 23:2 (April-June 2008).

Joaquin, Jeremiah Joven, "Feminism without Philosophy: A Polemic," in Kritike: An Online Journal of Philosophy, 10:1 (June 2016).

Llanera, Tracy P., "The Brown Babe's Burden," in Hypatia: A Journal of Feminist Philosophy, 34:2 (2019).

Mikkola, Mari, The Wrong of Injustice: Dehumanization and Its role in Feminist Philosophy (Oxford: Oxford University Press, 2016).

Prokhovnik, Raia, Rational Woman: A Feminist Critique of Dichotomy (London: Routledge, 1999).

Quito, Anne, “Emerita Quito: The Philippine's greatest female philosopher has died," in Quartz (17 September 2017), $<$ https://qz.com/725370/emerita-quito-the-greatest-forgottenfilipino-philosopher-has-died/>. 